\title{
Perlindungan Terhadap Orang Tanpa Kewarganegaraan (Stateless People) dalam Hukum Internasional (Studi Kasus Etnis Rohingya Di Myanmar)
}

\author{
Rahmawati Novia Sigit*; Novianti \\ Fakultas Hukum Universitas Jambi \\ *Coresponding author: rahmawatinovia695@gmail.com \\ Submission : 12 Desember 2019 \\ Revision : :04 Februari 2020 \\ Publication : 11 Februari 2020 \\ DOI $\quad:$ https://doi.org/10.36565/up.v1i1.8303
}

\begin{abstract}
The aim of this study was to describe and analyze the regulation of International Law relating to the protection of stateless people. In this study will examine the case of the Rohingya in Myanmar are without citizenship, this research also analyzes the efforts that need to be done in resolving cases of human rights violations by the Myanmar Government against Rohingyas based on the rules of International Law. The method used is normative juridical, i.e. research conducted on applicable legal norms, which is derived from international law. The approach used is the statute approach, case approach, and historical approach. This research was conducted by collecting legal instrument obtained from library materials which include primary, secondary and tertiary legal materials. Based on the results of the study it can be concluded that the protection of ethnicity in International Law has been carried out by the United Nations through various kinds of international declarations and conventions, which emphasizes human rights to protect ethnic groups throughout the world from discrimination and violence. The State of Myanmar needs to ratify the Convention on the status of non-citizenship in 1954 and the Convention on reducing the absence of citizenship in 1961 given the problem of non-citizenship in Myanmar is a very complex problem.
\end{abstract}

Keywords: Citizenship; Discrimination; Ethnic; Protection. 


\begin{abstract}
Abstrak
Penelitian ini bertujuan mendeskripsikan dan menganalisis pengaturan Hukum Internasional berhubungan dengan perlindungan terhadap orang tanpa kewargenegaraan (Stateless People). Dalam penelitian ini akan menelaah Kasus etnis Rohingya di Myanmar yang tanpa Kewarganegaraan, penelitian ini juga menganalisis upaya yang perlu dilakukan dalam menyelesaikan kasus pelanggaran HAM oleh Pemerintah Myanmar terhadap etnis Rohingya berdasarkan aturan-aturan Hukum Internasional. Adapun metode yang digunakan adalah yuridis normatif, yakni penelitian yang dilakukan atas norma-norma hukum yang berlaku, yang berasal dari hukum internasional.Pendekatan yang digunakan adalah pendekatan perundang-undangan, pendekatan kasus, dan pendekatan historis. Berdasarkan hasil penelitian dapat disimpulkan perlindungan terhadap etnis dalam Hukum Internasional telah dilakukan oleh PBB melalui berbagai macam deklarasi dan konvensikonvensi internasional, yang menegaskan mengenai Hak Asasi Manusia guna melindungi kelompok-kelompok etnis di seluruh penjuru dunia dari diskriminasi maupun kekerasan. Myanmar seharusnya meratifikasi Konvensi mengenai status orang yang tidak berkewarganegaraan 1954 dan Konvensi pengurangan ketiadaan kewarganegaraan 1961 sebagai bagian dari kewajiban dan tanggung jawabnya untuk melindungi dan memastikan bahwa etnis Rohingya memiliki kewarganegaraanya.
\end{abstract}

\title{
Kata Kunci: Diskriminasi; Etnis; Kewarganegaraan; Perlindungan.
}

\section{A. Pendahuluan}

Pasca Perang Dunia kedua, salah satu negara jajahan yang menjadi negara merdeka dan berdaulat di Asia Tenggara adalah Myanmar. Myanmar pernah dijajah Inggris dalam kurun waktu 1824-1948. ${ }^{1}$ Eksistensi Myanmar sebagai negara dalam komunitas internasional dan sesuai dengan Hukum Internasional memiliki empat unsur terbentuknya suatu negara. Pasal 1 Montevideo 1933 tentang hak dan kewajiban

1 Turnell, Sean. "MYANMAR'S FIFTY-YEAR AUTHORITARIAN TRAP." Journal of International Affairs 65, no. 1 (2011): 79-92. Accessed February 5, 2020.www.jstor.org/stable/24388183 
negara, sebenarnya hanya merupakan konvensi regional kawasan Amerika Regional, senantiasa menjadi rujukan pertanyaan kapan suatu entitas politik dapat dikatakan sebagai negara. Pasal 1 Konvensi Montevideo 1933 menyatakan bahwa karakteristik negara adalah sebagai berikut:

1. memiliki a defineted territory;

2. memiliki a permanent population;

3. memiliki pemerintahan (government)

4. memiliki kemampuan untuk melakukan hubungan internasional dengan negara lain (capacity to enter into relations with other states)."2

Unsur pertama adalah Defined Territory yang pasti (fixed territory) merupakan persyaratan mendasar adanya suatu negara.Meskipun demikian, tidak ada persyaratan dalam hukum internasional bahwa semua perbatasan sudah final dan tidak memiliki sengketa perbatasan lagi dengan negara-negara tetangga baik pada waktu memproklamirkan diri sebagai negara baru ataupun setelahnya. Kemudian unsur kedua adalah permanent population yaitu negara tidak akan exist tanpa penduduk. Persyaratan a permanent population dimaksudkan dengan stable community.Tidak ada persyaratan jumlah minimum penduduk yang harus dimiliki suatu negara. ${ }^{3}$

Unsur ketiga adalah Government yaitu Pemerintah yang dimaksud adalah pemerintah yang berdaulat, mampu menguasai organ-organ pemerintahan secara efektif dan memelihara ketertiban dan stabilitas dalam negeri yang bersangkutan. Unsur terakhir adalah kemampuan untuk melakukan hubungan dengan negara lain, merupakan manifestasi dari kedaulatan. Suatu negara yang merdeka, tidak dibawah kedaulatan negara lain akan mampu melakukan

2 Sefriani, Hukum Internasional Suatu Pengantar, Kedua, Yogyakarta, PT Raja Grafindo Persada, 2015, hal 94-95.

3 Ibid., hal 95-96. 
hubungan dengan negara lain. Suatu negara dikatakan merdeka (legal independence) jika wilayahnya tidak berada di bawah otoritas berdaulat yang sah dari negara lain. ${ }^{4}$

Salah satu unsur atau syarat berdirinya suatu negara adalah warga negara.Oleh karena itu, status kewarganegaraan bagi individu yang tinggal di dalam suatu negara adalah suatu hal yang sangat penting.Individu yang menjadi warga negara wajib mematuhi segala ketentuan hukum yang dibuat oleh negara dan negara wajib melindungi warganegaranya di mana pun mereka berada.

Begitu pentingnya status kewarganegaraan seseorang maka masyarakat internasional membuat beberapa instrumen hukum yang berhubungan dengan status kewarganegaraan dan hubungannya antara negara dengan warga negara, di dalam berbagai instrumen hukum tersebut dapat dijadikan sebagai dasar pelaksanaan perlindungan dan pemenuhan hak asasi manusia. Beberapa deklarasi atau dokumen lainnya yang berhubungan dengan hak-hak asasi manusia adalah sebagai berikut;

1. Universal Declaration of Human Rights (UDHR) 1948.

UDHR dan Kovenan Internasional mengenai Hak Sipil dan Politik 1966 (ICCPR) memberikan hak kesetaraan di depan hukum dan perlindungan yang sama menurut hukum. Kesetaraan hukum berarti bahwa setiap orang tidak dapat di diskriminasi berdasarkan ras, warna kulit, jenis kelamin, bahasa, agama, pandangan politik atau lainnya, latar belakang kebangsaan atau sosial, kekayaan, status kelahiran atau lainnya, berkaitan dengan perlakuan terhadap mereka di depan hukum. ${ }^{5}$

$4 \quad$ Ibid.,hal 96-97.

5 Erica Harper, International Law and Standard Applicable in Natural Disaster Situation, PT Grasindo, anggota Ikapi, Jakarta, 2009, hal 32. 
Peserikatan Bangsa-Bangsa (PBB) didirikan dengan tujuan utama untuk memelihara perdamaian dan keamanan, dan dengan demikian mencegah persengketaan atau konflik bersenjata yang mewarnai hubungan internasional. Dua perang dunia dalam jangka waktu hanya 30 tahuntelah memorak-porandakan Eropa Barat dan juga telah meluas keseluruh bagian dunia lainnya, termasuk Asia dan Pasifik. Setelah Perang Dunia II, pendapat umum cenderung lebih menginginkan suatu pendekatan yang lebih luas dengan menyepakati hak-hak minimum yang harus dapat dinikmati oleh setiap orang, apakah dia orang asli, imigran, atau orang asing. Ini dianggap layak setelah perlakuan terhadap individuindividu di Asia Tenggara dan Eropa Tengah selama Perang Dunia II.Sudah terbukti betapa sulitnya meramalkan siapa yang membutuhkan perlindungan dan tentu tidak mungkin untuk menjamin perlindungannya. ${ }^{6}$

2. International Covenant on Civil and Political Rights (ICCPR) and International Covenant on Economic, Social, and Cultural Rights (ICESCR) 1966.

International Covenant on Civil and Political Rights (ICCPR)adalah Kovenan Internasional tentang Hak Sipil dan Politik (KIHSP) mengandung hak-hak demokratis yang esensial, kebanyakan terkait dengan berfungsinya suatu negara dan hubungannya dengan warganegaranya. Hak untuk hidup dan kebebasan jelas merupakan hal yang harus dihormati oleh negara.Kebebasan individu dapat meningkatkan kualitas hidup dan menggambarkan hubungan antara negara dengan tiap individu.Partisipasi politik dan kebebasan untuk berekpresi jelas terkait dengan demokrasi dan konsep kebebasan politik dalam

6 Rhona K.M. Smith et al.,Hukum Hak Asasi Manusia, Cetakan Pertama, Pusat Studi Hak Asasi Manusia Universitas Islam Indonesia (PUSHAM UII), Yogyakarta, 2008, hal 87-88. 
suatu negara. Sedangkan International Covenant on Economic, Social, and Cultural Rights (ICESCR) 1966 perjanjian internasional mengenai Hak-hak Ekonomi, Sosial dan Budaya mulai berlaku sepuluh tahun kemudian yaitu tanggal 3 Januari 1976 dan sampai bulan Mei 1998 susah diratifikasi oleh 137 negara.

3. International Convention On The Elimination of All Forms of Racial Discrimination (ICERD) 1965.

Konvensi ini mengatur tentang penghapusan segala bentuk pembedaan, pengecualian, pembatasan atau pengutamaan berdasarkan ras, warna kulit, keturunan atau kebangsaan atau suku bangsa.

4. Convention On The Elimination of All Form of Discrimination Against Women 1979 (CEDAW)

Konvensi ini dianggap sebagai perjanjian piagam hak internasional untuk perempuan, hak asasi perempuan merupakan bagian dari hak asasi manusia, penegakkan hak asasi perempuan merupakan bagian dari penegakkan hak asasi manusia.Perlindungan, pemenuhan dan penghormatan hak asasi perempuan adalah tanggung jawab semua pihak bahkan warga negara secara perorangan punya tanggung jawab untuk melindungi dan memenuhi hak asasi perempuan.

5. Convention On The Rights of The Child 1989

Konvensi ini disahkan PBB untuk memberikan perlindungan terhadap anak dan menegakkan hak-hak anak di seluruh dunia pada tanggal 20 November 1989 dan mulai mempunyai kekuatan memaksa (entered in to force) pada tanggal 2 September 1990.

Perlindungan hak-hak kelompok minoritas dalam konteks keadaan darurat adalah penting karena kelompok tersebut sering terisolasi dari pelayanan-pelayanan pemerintah.Kelompok minoritas mungkin juga menghadapi diskriminasi dari negara atau dari masyarakat 
secara umum, yang semakin menyulitkan mereka mengakses tempat penampungan darurat dan bantuan kemanusiaan.Persoalan lebih lanjut adalah bahwa diskriminasi, jika tidak dipantau, dapat menjadi sumber ketidakstabilan sosial pada masa-masa darurat. ${ }^{7}$

Dengan banyaknya instrumen Hukum Internasional berkaitan dengan status Kewarganegaraan seseorang maka dapat disebut bahwa masalah status kewarganegaraan ini adalah sesuatu yang sangat penting tidak hanya bagi individu dan negara dimana seseorang itu berada tetapi juga dalam ranah Hukum Internasional.Namun dalam kenyataannya, kelompok minoritas yang menjadi komunitas yang terdiskriminasi dalam negara dimana mereka tinggal.

Di kawasan Asia Tenggara, tepatnya di negara Myanmar ada beberapa etnis yang mendiami suatu wilayah di negara Myanmar tersebut salah satunya adalah etnis Rohingya. Rohingya merupakan etnis "minoritas paling teraniaya di dunia", mereka adalah sekelompok etnis muslim yang telah tinggal selama berabad-abad di Myanmar yang mayoritasnya beragama Budhha.

Etnis Rohingya adalah salah satu dari berbagai etnis lainnya yang tidak dianggap sebagai salah satu dari 135 kelompok etnis resmi negara tersebut dan telah ditolak kewarganegaraannya di Myanmar sejak 1982 lalu. ${ }^{8}$ Undangundang ini menegaskan bahwa etnis minoritas di Rakhine harus membuktikan mereka sudah tinggal di Myanmar sebelum tahun 1823 untuk mendapatkan status kewarganegaraan Myanmar.Syarat ini secara efektif membuat etnis Rohingya tidak bisa mendapatkan status warga negara Myanmar. Bahkan, Departemen Imigrasi Myanmar mengakui

7 Erica Harper,,Op. Cit., hal. 161.

8 http://internasional.republika.co.id/berita/internasional/global/17/ 09/03/ovp7fi-sejarah-singkat-rohingya-di-myanmar, diakses tanggal17 Februari 2018, pukul 14.15 WIB.

Uti Possidetis: Journal of International Law, Vol. 1, No. 1(2020) 
dalam sensus penduduk yang akan digelar untuk kali pertama selama tiga dekade terakhir, tidak mencantumkan etnis Rohingya di dalam dokumen sensus. Penolakan soal status kewarganegaraan untuk etnis Rohingya ini bahkan mendapatkan dukungan dari banyak politisi, termasuk dari kelompok gerakan pro-demokrasi. ${ }^{9}$

Sejak awal 1950-an, sebagian Muslim di bagian Arakan atau Rakhine mengklaim diri mereka sebagai sebuah kelompok etnis yang berbeda dan terpisah, mereka mengindetifikasikan diri sebagai Rohingya.Mereka mengklaim, Rohingya sudah ada di Rakhine atau Burma sejak generasi terdahulu.Namun, klaim tersebut tidak berhasil.Mereka tidak mendapatkan pengakuan dari Myanmar dan keberadaannya diperdebatkan oleh kaum Budhha yang merupakan mayoritas di negara tersebut. Begitulah penjelasan singkat soal Rohingya menurut Jacques $\mathrm{P}$ Leider dalam tulisannya bertajuk Rohingya: The Name, The Movement, and Rhe Quest for Identity.Presiden Arakan Rohingya National Organization (ARNO), Nurul Islam, mengatakan Rohingya telah tinggal sejak dahulu kala.Mereka merupakan orang-orang dengan budaya dan peradaban yang berbeda-beda.Jika ditelusuri, nenek moyang mereka berasal dari orang Arab, Moor, Pathan, Bengali, dan beberapa orang Indo-Mongoloid.Pemukiman Muslim di Arakan telah ada sejak abad ke-7 Masehi. ${ }^{10}$

Naiknya Junta Militer ini menandai dimulainya kisah horor bagi etnis Rohingya di Myanmar.Ne Win saat ini memberlakukan hukum kewarganegaraan yang menyatakan penolakan status kewarganegaraan atas etnis

9 http://internasional.kompas.com/read/2013/11/21/1933040/Myan mar.Tolak.Beri.Status.Warga.Negara.untuk.Etnis.Rohingya, diakses tanggal 17 Februari 2018, pukul 11.20 WIB.

10 http://internasional.republika.co.id/berita/internasional/global/17 109/03/ovp7fi-sejarah-singkat-rohingya-di-myanmar, diakses tanggal 17 Februari 2018, pukul 14.15 WIB.

Uti Possidetis: Journal of International Law, Vol. 1, No. 3 (2020) 
Rohingya.Pemerintah mengklaim Rohingya tidak memenuhi syarat sebagai warga negara.Undang-undang Kewarganegaraan yang disusun militer pada 1982 mendefinisikan warga negara sebagai kelompok etnis yang secara permanen telah menetap dalam batas-batas modern Myanmar sebelum 1823.11

Undang-Undang Kewarganegaraan 1948 kemudian digantikan dengan Undang-Undang Kewarganegaraan 1982 yang mengatur tiga jenis kewarganegaraan, yaitu:

The expressions contained in this Law shall have the following meanings:

a) "State" means the Socialist Republic of the Union of Burma;

b) "Citizen" means a Burma Citizen;

c) "Associate Citizen" means an associate citizen prescribed by this Law;

d) "Naturalized Citizen" means a prescribed by this Law;

e) "Foreigner" means a person who is not a citizen or a naturalized citizen;

f) “Certificate of citizenship" means a certificate of citizenship granted under the Union Citizenship (Election) Act, 1948 or the Union Citizenship (Election) Act, 1948 or this Law;

g) "Certificate of Associate Citizenship" means a certificate of associate citizenship granted under this Law;

h) "Certificate of Naturalized Citizenship" means a certificate of naturalized citizenship granted under this law;

11 http://www.sindoweekly.com/global/magz/no-29-tahun-vi/rohi ngya-kaum-terbuang, diakses tanggal 18 Februari 2018, pukul 03.40 WIB.

Uti Possidetis: Journal of International Law, Vol. 1, No. 1(2020) 
i) "Central Body established under this Law.12

Pengecualian orang-orang Rohingya dari daftar ras nasional, kecuali Dewan Negara merubah daftar tersebut, orang-orang Rohingya tidak dapat memiliki kewarganegaraan penuh (Full Citizens). Kesempatan bagi orang-orang Rohingya adalah pada Associate Citizens dan Naturalised Citizens, namun kedua ini mensyaratkan untuk menunjukkan dokumen-dokumen kependudukan yang dijadikan bukti yang meyakinkan atas keberadaan mereka sebelum tahun 1823 maupun 1948, yang mana tidak dimiliki oleh orang-orang Rohingya.

Dalam dokumen Citizenship Act 1982 dimana pemerintahan Myanmar tidak mengakui jika etnik Rohingya sebagai warga Negara Myanmar.Semenjak tidak diakuinya etnik Rohingya sebagai dari bahagian bangsa Myanmar, dan sejak itu pulalah noda hitam mewarnai perjalanan sejarah suatu suku yang tidak diakui sebagai bangsa oleh negaranya.Pelanggaran terhadap Hak Asasi Manusia (HAM) terhadap rakyat yang tidak bernegara ini terjadi secara sistematik setiap harinya sampai saat ini. ${ }^{13}$

Ye Htut menegaskan pemerintah benar-benar menolak sebutan Rohingya dengan mengatakan hanya ada kelompok Bengali di Rakhine yang diperbolehkan mendapat kewarganegaraan menurut undang-undang pada 1982.Aturan itu menyatakan, untuk mendapat kewarganegaraan maka kelompok minoritas harus membuktikan mereka sudah tinggal di Myanmar sejak sebelum 1823. Undang-undang itu mengakui delapan ras dan 130 kelompok etnis namun

12 Burma Citizenship Law Pasal 1 Ayat 2.

13 https://www.kompasiana.com/wisnuandangjaya/nobel-perdamai an-dalam-nasib-etnis-rohingya 584b9c509373e538b5f10a, diakses tanggal 24 Februari 2018, pukul 23.44 WIB.

Uti Possidetis: Journal of International Law, Vol. 1, No. 3 (2020) 
menolak memberikan kewarganegaraan bagi sekitar 800 ribu muslim Rohingya. ${ }^{14}$

Sementara dalam Hukum Internasional terdapat instrumen hukum internasional yang khusus melindungi orang tanpa kewarganegaraan, di antaranya;

1. Convention Relating to the Status of Stateless Person 1954

Konvensi ini mengenai orang-orang yang tidak memiliki kewarganegaraan.

2. International Convention on Reduction of Statelessness 1961

Konvensi ini menangani kasus statelesness dan usaha untuk mengurangi terciptanya kondisi tersebut.

Sejak tanggal 4 April 1948 Myanmar telah menjadi negara anggota PBB, tetapi Myanmar belum meratifikasi kovenan-kovenan penting tentang Hak Asasi Manusia (HAM) terutama Konvensi tentang status orang tanpa kewarganegaraan 1954 dan Konvensi tentang pengurangan orang tanpa kewarganegaraan 1961.

Semenjak adanya tindakan represif dari militer Myanmar, muslim Rohingya memilih untuk meninggalkan kampung halaman. Mereka mencari pelarian ke negara lain untuk mengungsi. Mereka tidak peduli negara itu berstatuskan tanpa kewarganegaraan (stateless).Muslim Rohingya itu tersebar disejumlah negara.Saat ini ada sekitar 500 ribu pengungsi Rohingya di Bangladesh.Ratusan ribu lainnya tersebar di sejumlah negara.Diantaranya, 400 ribu di Arab Saudi, 200 ribu di Pakistan, 100 ribu di Thailand, dan 11.941 di Indonesia.Jumlah mereka terus bertambah di berbagai negara.

14 https://m.merdeka.com/dunia/myanmar-tolak-beri-kewarganega raan-buat-muslim-rohingya-html, diakses tanggal 25 Februari 2018, pukul 00.09 WIB.

Uti Possidetis: Journal of International Law, Vol. 1, No. 1(2020) 
Populasi etnis Rohingya yang sekitar 1,3 juta di Myanmar susut. 15

Akibat dari pemberlakuan Undang-undang Kewarganegaraan Myanmar 1982 dan dengan tidak meratifikasi konvensi-konvensi yang terkait dengan hak-hak asasi manusia mengakibatkan etnis Rohingya mendapatkan perlakuan diskriminasi dari pihak manapun terutama dari negaranya sendiri dan tidak mendapatkan perlindungan sebagai orang yang tidak memiliki kewarganegaraan (stateless people).

Artikel ini membahas Bagaimana pengaturan di dalam Hukum Internasional yang terkait dengan orang tanpa kewarganegaraan (Stateless People) dan Bagaimana perlindungan hukum terhadap etnis Rohingya menurut Hukum Internasional.Karena Pelanggaran HAM yang telah dilakukan oleh junta militer Myanmar yang sistematis dan konsisten ini membuat terganggunya stabilitas regional di negara-negara bagian Asia Tenggara, karena semakin banyaknya pengungsi-pengungsi etnis Rohingya yang semakin besar kepada negara tetangga, terutama di negara Bangladesh.Setelah melihat adanya perlakuan negara Myanmar yang tidak perduli dengan warga negaranya mengakibatkan komunitas internasional harus turut serta melakukan intervensi dan melakukan pertanggung jawaban negara dengan mempertimbangkan aturan-aturan yang terkait dengan perlindungan orang tanpa kewarganegaraan (Stateless People) dan mengimplikasikannya kepada kasus etnis Rohingya di Myanmar.

\section{B. Pembahasan dan analisis}

15 https://www.jawapos.com/read/2017/09/03/154825/negaranegara-tujuan-pelarian-muslim-rohingya-untuk-mengungsi-diri, diakses tanggal 06 Maret 2018, pukul 23.02 WIB.

Uti Possidetis: Journal of International Law, Vol. 1, No. 3 (2020) 


\section{Aturan-Aturan dalam Hukum Internasional yang Berhubungan Dengan Perlindungan Terhadap Stateless People.}

Pada saat ini individu telah mendapatkan pengokohan akan statusnya sebagai subjek hukum internasional melalui rezim hukum HAM internasional. Protokol pertama ICPPR secara jelas memberikan hak bagi individu untuk melakukan 'komunikasi' terhadap organ traktatnya, The Human Rights Committee. Sedangkan pada tingkat regional individu memiliki kemampuan yang sama sebagaimana halnya subjek hukum internasional, yaitu melakukan tindakan sebagaimana yang diberikan Protokol pertama. ${ }^{16}$

Setiap orang memiliki hak atas status Kewarganegaraan, hak-hak ini diatur dalam Deklarasi Universal Hak-Hak Asasi Manusia 1948 (DUHAM) yang mengatur hak atas Kewarganegaraan.Ketentuan ini diatur di dalam Pasal 15 ayat (1) yaitu "Setiap orang berhak atas sesuatu kewarganegaraan”.Dan dalam Pasal 15 ayat (2) ditentukan yaitu "Tidak seorang pun dapat dicabut kewarganegaraannyasecara sewenang-wenang atau ditolak haknya untuk mengubahkewarganegarannya."

Berdasarkan ketentuan pasal di atas dapat dilihat bahwa menjadi warga negara dari suatu negara adalah merupakan hak dasar/hak asasi yang melekat pada diri seseorang (individu).Dan status kewarganegaraan seseorang tidak dapat dicabut secara sewenang-wenang.Karena hak atas kewarganegaraan ini merupakan salah satu hak asasi manusia dan sebagai landasan identitas, martabat, keadilan dan keamanan.Status kewarganegaraan seseorang merupakan bukti keanggotaannya dalam organisasi kekuasaan yang disebut negara.Oleh sebab itu, negara wajib

16 Jawahir Thontowi dan Pranoto Iskandar, Hukum Internasional Kontemporer, Cetakan Pertama, PT Refika Aditama, Yogyakarta, 2006, hal. 121. 
melindunginya.Perlindungan yang dimaksud disini berdimensi HAM dan KAM (Hak Asasi Manusia dan Kewajiban Asasi Manusia). Selain itu, dalam dimensi Hukum Publik, status kewarganegaraan seseorang akan menimbulkan konsekuensi bahwa setiap orang yang disebut sebagai Warga Negara harus tunduk dan patuh pada hukum-hukum negara sebagai manifestasi kehendak bersama dalam ikatan kontrak sosial yang merupakan persyaratan normatif terbentuknya negara. ${ }^{17}$

Instrumen Internasional lainnya yang berkaitan tentang kewarganegaraan adalah Konvensi Internasional tentang Penghapusan Segala Bentuk Diskriminasi Rasial 1979 (International Convention on The Elimination of All Forms of Racial Discrimination 1979). Diskriminasi rasial sangat bermasalah karena orang-orang didiskriminasi semata-mata karena warna kulit mereka, ras mereka, suatu ciri yang mereka sendiri tidak dapat mengendalikannya.Elemen-elemen diskriminasi rasial juga berkaitan dengan perbudakan dan praktik perbudakan, sebagaimana dinyatakan dalam Deklarasi yang diterima pada akhir Konferensi sedunia menentang Rasisme, Diskriminasi Rasial, xenophobia dan ketidak toleransian yang terkait pada tahun 2001.18

Orang dapat menjadi tidak mempunyai status kewarganegaraan sebagai salah satu efek dari pelaksanaan birokrasi yang buruk, khususnya mereka, kelompok yang mengalami diskriminasi rasial dan pejabat pemerintah atau kendala birokrasi yang berbelit-belit. ${ }^{19}$

17 https://www.kompasiana.com/haramli/mempersoalkan-status-ke warganegaraan-para-terdakwa-kasus-makar-bagian-2 550dfdc5a 3331aa2dba7dd3\#, diakses tanggal 25 Februari 2018, pukul 17.03 WIB.

18 Rhona K.M. Smith et al, Op. Cit., hal. 160.

19 https://www.kompasiana.com/isharyanto/mereka-yang-tidakmempunyai-kewarganegaraan 553300eb6ea8345b088b458c,Op. Cit., 
Adapun instrumen hukum yang mengatur tentang hal ini yaitu Convention Relating to The Stateless Person 1954 (Konvensi yang berhubungan dengan Orang-orang tanpa Kewarganegaraan). Secara garis besar konvensi ini mengatur hal-hal yang berhubungan dengan Stateless Person sebagai berikut:

1. Pasal 1, Stateless Persons adalah orang-orang yang dianggap bukan warga negara berdasarkan ketentuan hukum negara yang bersangkutan ( $d e$ jure stateless). Konvensi ini tidak berlaku bagi mereka yang: sedang menerima perlindungan atau bantuan dari organ PBB selain UNHCR: mempunyai hak dan kewajiban sebagai warga negara dimana ia bertempat tinggal; melakukan kejahatan terhadap perdamaian, kemanusiaan, dan kejahatan perang; melakukan kejahatan non-politis serius di negara lain; terbukti bersalah melanggar tujuan dan prinsip PBB.

2. Pasal 2, Stateless persons wajib tunduk pada hukum dan ketentuan yang berlaku di negara dimana ia tinggal, termasuk menjaga ketertiban umum.

3. Pasal 3, Negara peserta wajib menerapkan seluruh isi konvensi tanpa diskriminasi terhadap ras, agama, negara asal.

4. Pasal 4, Memperlakukan stateless persons layaknya warga negara dalam hal kebebasan melaksanakan agama dan pendidikan keagamaan bagi anak-anak mereka.

5. Pasal 7, Setelah masa tinggal 3 tahun, stateless persons berhak dibebaskan dari resiprositas legislatif (legislative reciprocity) di wilayah negaranegara peserta.

Berdasarkan ketentuan-ketentuan di atas, bila diperhatikan dengan seksama, ada beberapa kewajiban yang 
harus dipatuhi oleh Stateless Person yang berada dalam wilayah suatu negara yaitu:

1. Stateless Persons wajib tunduk pada hukum dan ketentuan yang berlaku di negara dimana ia tinggal, termasuk menjaga ketertiban umum.

2. Setelah masa tinggal 3 tahun, Stateless Persons berhak dibebaskan dari resiprositas legislatif (legislative reciprocity) di wilayah negara-negara peserta.

Konvensi lain yang berhubungan dengan keadaaan tanpa kewarganegaraan adalah Convention on The Reduction of Statelessness 1961 (Konvensi tentang Pengurangan Keadaan Tanpa Kewarganegaraan), terdapat suatu konvensi internasional yang menjelaskan bahwa seseorang dapat dicabut dari kewarganegaraannya karena adanya berbagai alasan, konvensi tersebut ialah Konvensi tentang Pengurangan Penduduk yang Tidak Memiliki Kewarganegaraan 1961. Penjelasan dalam konvensi tersebut ada dalam paraphrase adalah sebagai berikut:

1. Pasal 7 ayat 4 , seseorang yang dinaturalisasi dapat kehilangan kewarganegaraannya dengan alasan bertempat tinggal di negara lain dalam jangka waktu tidak kurang dari tujuh tahun berturut-turut, Ketentuan ini ditetapkan oleh Undang-undang negara yang bersangkutan, jika ia gagal untuk menyatakan kepada penguasa yang tepat untuk keinginannya tetap menjadi warga negaranya;

2. Pasal 8 ayat $2 \mathrm{~b}$, kewarganegaraan yang sudah diperoleh dengan perwakilan yang salah atau dengan penipuan;

3. Pasal 8 ayat $3 a$, orang itu tidak konsisten dengan kewajibannya untuk setia pada negara dengan cara tidak memperdulikan larangan yang melarang pemberian layanan atau bekerja pada negara lain 
atau dengan cara yang sangat barbahaya untuk kepentingan vital negaranya;

4. Pasal 8 ayat $3 \mathrm{~b}$, orang itu telah bersumpah atau membuat pernyataan yang formal tentang kesetiaan kepada negara lainnya atau telah memberikan suatu bukti yang pasti bahwa ia meninggalkan kesetiaannya kepada negaranya.

Convention on The Elimination of All Forms of Discrimination Against Women 1979 (CEDAW). Sampai bulan Mei 1998, Konvensi ini telah diratifikasi oleh lebih dari 161 negara. Konvensi ini memberikan jaminan hak yang sama di depan hukum antara wanita dan pria dan menjelaskan tindakan-tindakan untuk menghapuskan diskriminasi terhadap wanita sehubungan dengan kehidupan politik dan publik, kewarganegaraan, pendidikan, lapangan kerja, kesehatan, perkawinan dan keluarga. Konvensi ini juga mendirikan Komite tentang Penghapusan Diskriminasi terhadap Wanita sebagai badan yang memantau implementasi ketentuan-ketentuan Konvensi dan membahas laporan dari negara-negara pihak. Perundingan-perundingan telah dilakukan semenjak tahun 1996 untuk membuat suatu protokol dari Konvensi yang akan memungkinkan individuindividu untuk menyampaikan pengaduan mereka atas pelanggaran-pelanggaran yang dilakukan terhadap Konvensi. ${ }^{20}$

Selanjutnya terdapat Konvensi lainnya yang berhubungan dengan Stateless Persons (Orang-orang tanpa Kewarganegaraan) yaitu Convention on the Elimination of all Forms of Discrimination Against Women, disingkat (CEDAW).Secara umum, konvensi ini memberikan fondasi dalam rangka mewujudkan kesetaraan antara kaum perempuan dan kaum laki-laki.Hal tersebut dipastikan dengan

20 Boer Mauna, Hukum Internasional; Pengertian, Peranan, dan Fungsi dalam era Dinamika Global, Edisi Pertama Cetakan Ke-4, PT. Alumni, Bandung, 2003, hal. 605-606. 
tersedianya akses terhadap kesetaraan itu sendiri baik dalam kehidupan politik dan ruang-ruang publik lainnya dari mulai pendidikan, kesehatan dan ketenagakerjaan.Negara-negara yang ikut andil dalam konvensi ini telah siap untuk melakukan segala jenis tindakan yang tepat untuk melindungi kaum perempuan. ${ }^{21}$

Dalam Convention on the Rights of the Child 1989, konvensi tentang Hak Anak mungkin merupakan instrumen tambahan terkemuka dari semua instrumen tambahan. Karena secara inheren mereka rentan, karena alasan fisiologis, anakanak bergantung pada orang lain untuk kelangsungan hidup mereka dengan cara yang tidak dapat dibandingkan dengan kelompok-kelompok lain yang telah diberikan perlindungan cermat (pengungsi, perempuan, pekerjaan migran, narapidana, dan lain-lain). Anak juga dapat menderita "pelanggaran sekunder hak asasi manusia, apabila hak atas pemelihara utama (primary carier) mereka dilanggar.Jadi memastikan penghormatan terhadap hak-hak universal harus tetap merupakan prioritas, karena hak anak dan hak orang yang memeliharanya seringkali berkaitan dengan yang sampai pada tingkatan tidak dapat dipisahkan, terutama selama tahuntahun pertumbuhan dan perkembangan anak. ${ }^{22}$

Secara khusus diatur ketentuan mengenai hak anak atas kewarganegaraan. Ketentuan ini diatur dalam Pasal 7 yaitu sebagai berikut :

1. Anak harus didaftarkan segera sesudah kelahiran dan harus mempunyai hak sejak lahir atas suatu nama, hak untuk memperoleh kewarganegaraan,

21 Siti Hediati Rahminita, Implementasi Konvensi Penghapusan Segala Bentuk Diskriminasi Terhadap Perempuan (CEDAW) Dan Korelasinya Terhadap Ketidaksetaraan Gender, Jurnal Ilmu Sosial, Vol 16 No. 1 Februari 2017, hal. 42.

22 Rhona K.M. Smith et al., Op. Cit, hal. 138. 
dan sejauh mungkin, hak untuk mengetahui dan dirawat oleh orang tuanya.

2. Negara-negara Pihak harus menjamin pelaksanaan hak-hak ini sesuai dengan hukum nasional mereka dan kewajiban mereka menurut instrumeninstrumen Internasional yang relevan dalam bidang ini, terutama apabila anak sebaliknya akan tidak berkewarganegaraan.

Ketentuan tentang hak anak atas kewarganegaraan juga sebelumnya diatur dalam International Covenant on Civil and Political Rights 1966 yang dalam Pasal 24 menetapkan:

1. Setiap anak berhak untuk mendapat hak atas langkah-langkah perlindungan karena statusnya sebagai anak di bawah umur, terhadap keluarga, masyarakat dan Negara tanpa diskriminasi berdasarkan ras, warna, jenis kelamin, bahasa, agama, asal-usul kebangsaan atau sosial, kekayaan atau kelahiran.

2. Setiap anak harus didaftarkan segera setelah kelahirannya dan harus memperoleh suatu nama.

3. Setiap anak berhak untuk memperoleh kewarganegaraan

Dari sudut pandang HAM status berkewarganegaraan merupakan hak asasi seseorang. Bahkan secara tegas dalam Deklarasi Umum Hak Asasi Manusia (DUHAM) Pasal 15 ayat 1 seperti yang dikutip sebelumnya menekankan bahwa setiap orang berhak atas kewarganegaraan. Dan pada Pasal yang sama ditentukan bahwa tidak seorang pun dapat di cabut kewarganegaraannya secara sewenang-wenang bahkan oleh negara sekalipun.

Meskipun ketentuan-ketentuan yang terdapat dalam Instrumen-instrumen tersebut merupakan perlindungan terhadap hak atas kewarganegaraan, hal tersebut dikarenakan kelompok etnis terdiri dari individu-individu yang mengelompokkan diri dikarenakan asal usul budaya yang 
sama. Namun pada faktanya masih ditemukan orang yang tidak mempunyai status kewarganegaraan di seluruh benua dan tiap negara.Mereka menunjukkan ketimpangan status kewarganegaraan dewasa ini dan mereka adalah golongan manusia paling rentan didunia.

Dalam keadaan ini Badan PBB yang mengurusi masalah pengungsi United Nations High Commission for Refugees (UNHCR) berpartisipasi dalam menyusun rancangan Konvensi 1954 yaitu Convention Relating to the Status of Stateless Persons yang mengatur tentang Orang-orang yang tidak memiliki status kewarganegaraan dan Konvensi 1961 Convention Reduction Statelessness tentang pengurangan orang-orang tanpa kewarganegaraan. Pada tahun 1974, UNHCR ditunjuk Majelis Umum untuk menyelesaikan persoalan orang yang tidak mempunyai status kewarganegaraan di bawah Konvensi 1961 untuk memberikan bantuan kepada mereka guna mengajukan permohonan kepada negara yang berwenang. ${ }^{23}$

Konsep martabat kemanusiaan melandasi hak-hak sipil dan politik maupun ekonomi, sosial, dan budaya.Hak-hak ini tidak bisa diberikan maupun dicabut.Martabat manusia teringkari bilamana hak-hak sipil dan politik serta ekonomi, sosial dan budaya tidak dijamin.Sementara itu, perkembangan instrumen hak asasi manusia juga semakin menjelaskan tak terpisahkannya hak-hak sipil dan hak-hak ekonomi, sosial dan budaya.

Beberapa konvensi ini diharapkan dapat memberikan perlindungan dan atau mengurangi bahkan menghilangkan status orang tanpa kewarganegaraan (Statelessness) diseluruh dunia. Kedua konvensi ini merupakan instrumen hukum primer Internasional yang mendefinisikan dan mengatur

23 https://www.kompasiana.com, diakses tanggal 2 Februari 2018, pukul 12.26 WIB.

Uti Possidetis: Journal of International Law, Vol. 1, No. 3 (2020) 
status perlakuan terhadap orang-orang tanpa kewarganegaraan dan menguraikan mekanisme untuk mencegah dan mengurangi keadaan tanpa kewarganegaraan.

\section{Perlindungan Etnis Rohingya Sebagai Orang TanpaKewarganegaraan dalam Hukum Internasional.}

Sudah bertahun-tahun pemerintah Myanmar menyangkal kewarganegaraan orang-orang Rohingya, yang membuat merekahidup dalam keadaan tanpa kewarganegaraan atau stateless persons.Padadasarnya pelanggaran-pelanggaran HAM yang di alami oleh masyarakat Rohingya merupakan hasil dari penyangkalan kewarganegaraan mereka yang membuat mereka menjadi sasaran dari serangkaian peraturan yang diskriminatif dan tidak adanya perlindungan dari negara mereka.

Konflik Etnis Rohingya di Rakhine merupakan konflik yang berkepanjangan. Serangan terhadap pos penjagaan oleh etnis Muslim Rohingya dijadikan momentum untuk melancarkan serangan balik, hanya saja apa yang dilakukan oleh tentara Myanmar merupakan tindakan persekusi yang mengarah kepada tindakan Genosida dengan tujuan Pembersihan Etnis Muslim Rohingya. ${ }^{24}$

Menurut Mochtar Kusumaatmadja, hukum internasional (publik) adalah keseluruhan kaidah dan asas hukum yang mengatur hubungan atau persoalan yang melintasi batas negara (hubungan internasional) yang bukan bersifat perdata. ${ }^{25}$ Hukum internasional merupakan sistem hukum yang berkaitan dengan hubungan antar negara yang memberikan pedoman, aturan dan cara atau metode

24 https://www.kompasiana.com/i.addi wisudawan/59c2173db9a42 c30e664aac2/rohingya-dalam-kacamata-hukum-internasional, diakses tanggal 25 Februari 2018, pukul 23.57 WIB.

25 Mochtar Kusumatmadja dan Etty R. Agoes, Pengantar Hukum Internasional, PT ALUMNI, Bandung, 2013, hal. 1. 
bagaimana suatu sengketa dapat diselesaikan dengan damai. Kasus yang menimpa warga Rohingya yang di diskriminasi oleh negaranya sendiri menjadi perhatian oleh negara-negara lain.

Dapat dilihat dengan jelas tidak ada kesetaraan dalam hidup berdampingan dengan perbedaan keyakinan. Hilangnya prinsip kesetaraan bahwa semua orang adalah sama di hadapan hukum, tidak ada produk hukum yang berlaku untuk beberapa orang. Telah terjadi diskriminasi kaum minoritas Rohingya, kekerasan dan penindasan dirasakan oleh kaum minoritas tersebut.Pemerintah yang tidak mengakui adanya Rohingya semakin sulit memperoleh hak asasinya untuk mendapatkan perlindungan.

Guru Besar Hukum Internasional UI Hikmahanto Juwana menegaskan masalah Rohingya tidak berkaitan dengan agama melainkan ketidakjelasan status kewarganegaraan etnis Rohingya sebagai warga negara Myanmar selama berpuluhpuluh tahun. Saat ini berkembang di Indonesia seolah masalah yang terjadi terhadap etnis Rohingya sebagai masalah antar agama, padahal masalah ini tidak berkaitan dengan agama, melainkan tidak diakuinya etnis Rohingya sebagai warga Myanmar selama berpuluh-puluh tahun. Masalah lainnya adalah adanya pembiaran dari pemerintah Myanmar atas perlakuan tidak manusiawi aparat keamanan terhadap etnis Rohingya sehingga terjadi eksodus besar-besaran etnis tersebut. Berbagai pejabat dan tokoh dunia telah mengkategorikan hal ini sebagai ethnic cleaning dan genosida yang merupakan kejahatan internasional. ${ }^{26}$

Dari negara Indonesia sendiri Menteri Luar Negeri Retno Marsudi sudah bertemu dengan Aung San Suu Kyi untuk membicarakan upaya penyelesaian masalah Rohingya. Dalam

26 http://m.republika.co.id/berita/internasional/global/17/09/05/o vsaxl-hikmahanto-masalah-rohingya-terkait-status-kewarganega raan, diakses tanggal 25 Februari 2018, pukul 21.21 WIB.

Uti Possidetis: Journal of International Law, Vol. 1, No. 3 (2020) 
Pertemuan tersebut, Menlu menyerahkan Formula 4+1, yang isinya:

1. Mengembalikan stabilitas dan keamanan.

2. Menahan diri secara maksimal dan tidak menggunakan kekerasan.

3. Perlindungan kepada semua orang yang berada di negara bagian Rakhine, tanpa memandang suku dan agama.

4. Pentingnya segera dibuka akses untuk bantuan keamanan. ${ }^{27}$

Pelapor Khusus PBB soal hak asasi manusia untuk Myanmar, Yanghee Lee, sudah mengkritik pemimpin de facto negara itu, Aung San Suu Kyi, karena gagal melindungi minoritas Muslim Rohingya. Sementara itu, berbagai lembaga pemantau Hak Asasi Manusia (HAM) melanjutkan desakan agar pemerintah Myanmar mengizinkan Tim Pencari Fakta (TPF) yang dibentuk Dewan HAM PBB untuk masuk dan mengungkapkan kebenaran peristiwa kekerasan di negara bagian Rakhine, tempat tinggal umat sebagian besar Muslim Rohingya. ${ }^{28}$

Sebenarnya PBB dalam hal ini telah mengutus UNHCR untuk datang ke Myanmar dalam mengatasi etnis Rohingya yang masih berada di kawasan Myanmar sebagai bentuk perhatian masyarakat internasional atas kasus Rohingya. Banyak sekali bantuan yang dilakukan oleh UNHCR pada etnis ini seperti mengadakan pendidikan informal, membangun camp pengungsian kesehatan dan masih banyak lainnya.Tetapi peran UNHCR disini hanyalah sebagai pembantu yang bersifat sementara, mereka tidak dapat menebus kebijakan yang diambil pemerintah Myanmar.Hal ini dibuktikan dengan permasalahan Rohingya sampai saat ini masih tetap ada

27 http://www.bbc.com/indonesia/dunia-41149698, diakses tanggal 25 Februari 2018, pukul 21.03 WIB.

Ibid., 
sejalan dengan masih eksisnya bantuan UNHCR di Myanmar. Keberadaan UNHCR di Myanmar sejak tahun 90'an membuktikan bahwa usaha yang dilakukan oleh PBB dimulai dari dalam negeri myanmar sendiri. Mereka mencoba untuk memenuhi kebutuhan dasar etnis ini yang masih berada dalam wilayah kedaulatan Myanmar.Tetapi kembali lagi, usaha yang dilakukan oleh PBB ini tidak dapat mencegah perlakuan diskriminasi yang dilakukan pemerintah Myanmar sehingga etnis Rohingya tetap melarikan diri ke luar wilayah Myanmar.

Sementara itu wakil Organization of Islamic Coorporation (OIC) di PBB mendesak PBB untuk menekan pemerintahan Myanmar agar menyelesaikan konflik Rohingya. Myanmar tidak dapat bergabung dengan komunitas demokratis negara-negara lain jika tidak melindungi hak-hak minoritas di negerinya. ${ }^{29}$

Sementara itu, tim pencari fakta PBB yang dipimpin oleh Koffi Annan mengungkapkan tindakan persekusi, diskriminasi dan perlakuan terhadap minoritas Rohingya telah mencapai kejahatan kemanusiaan. Oleh karena itu, kasus Rohingya perlu ditangani dengan menggunakan perspektif dan mekanisme hak asasi manusia internasional.Pelaku kekerasan harus dituntut berdasarkan hukum pidana internasional atas kesalahan mereka dan korbannya harus mendapatkan pemulihan. Selanjutnya di bawah Resolusi yang sama, Pemerintah Indonesia sebagai anggota masyarakat internasional berkewajiban mendorong dan membantu Myanmar untuk melaksanakan tanggung jawab dan mendukung PBB dalam membangun peringatan sejak dini. ${ }^{30}$

Di sisi lain secara Khusus, Indonesia sebagai anggota OKI berkepentingan mendesak PBB untuk memberikan sanksi

29 http://nasional.kompas.com/read/2017/09/04/06474181/ylbhipelanggaran-ham-warga-rohingya-harus-dituntut-pidana-inter nasional, diakses tanggal 25 Februari 2018, pukul 22.16 WIB.

30 Ibid., 
tegas terhadap pemimpin Myanmar dengan mengajukan ke International Criminal Court (ICC) atas tuduhan upaya genosida secara sistematis terhadap Muslim Rohingya. Tragedi kemanusiaan yang menimpa Muslim Rohingya di Myanmar jelas merupakan amanat penderitaan Muslim internasional sebagai spirit kemanusiaan atas nama ketidakadilan yang merampas hak-hak kemanusiaan. ASEAN juga sebenarnya sudah mengadopsi prinsip-prinsip penegakkan hak asasi manusia melalui dibentuknya ASEAN Intergovermental Commission on Human Rights (AICHR) pada tahun 2009.

Kelemahan dari ASEAN Intergovermental Commission on Human Right (AICHR) adalah perbedaan yang berlaku dalam memberikan sanksi dan tekanan terhadap negara yang telah melanggar. Faktanya, beberapa konvensi yang telah disusun oleh anggota ASEAN memunculkan masalah yang komplek mengenai penegakan hak asasi manusia. Kelemahan ini dapat dilihat dari khasus Myanmar yang merupakan negara yang paling bermasalah dengan perlindungan hak asasi manusia di wilayah Asia Tenggara.

Kofi Annan, mendesak negara di ASEAN untuk mengubah kesepakatan politik luar negeri yang berasaskan "does not interfere with members" internal affairs (noninterference), yang berkaitan dengan kasus Aung San Suu Kyi' di Myanmar pada tahun 2007. Tapi hingga saat ini peran aktif anggota ASEAN tidak tampak dan tidak memperlihatkan peran yang nyata. ${ }^{31}$

Namun kembali lagi bahwa tidak banyak yang dapat dilakukan masyarakat internasional dalam menangani masalah Rohingya. Kedaulatan suatu negara sangat dijunjung

31 Bangun, B. (2019). ASEAN Intergovernmental Commission on Human Rights and Effectiveness of Fulfilling Human Rights Obligations of ASEAN Members States. Jambe Law Journal, 1(2), 231-249. https://doi.org/https://doi.org/10.22437/jlj.1.2.231249. 
tinggi oleh masyarakat internasional.Sehingga masyarakat internasional tidak dapat melakukan intervensi terhadap Myanmar karena mereka sendiri. Terlebih lagi pemerintah Myanmar sangatlah menutup mengenai permasalahan seperti ini.

\section{Simpulan}

Berdasarkan pembahasan pada bab-bab terdahulu dapat disimpulkan sebagai bahwa perlindungan terhadap orang tanpa kewarganegaraan dalam hukum internasional telah diatur dalam Deklarasi Universal Hak-Hak Asasi Manusia 1948 (Universal Declaration of Human Rights 1948), Konvensi mengenai status orang tanpa kewarganegaraan 1954 (Convention Relating to the Status of Statelesness Persons 1954) dan Konvensi mengenai pengurangan ketiadaan kewarganegaraan 1961 (Convention on the Reduction of Statelessness 1961) oleh PBB yang menegaskan mengenai Hak Asasi Manusia guna melindungi kelompok-kelompok etnis di seluruh penjuru dunia dari diskriminasi maupun kekerasan, terutama kelompok yang tidak memiliki kewarganegaraan.

Berdasarkaninstrumenthukum internasionalpemerintah Myanmar dapat dianggap telah melanggar standar-standar Internasional melalui pemberlakuan Undang-Undang Kewarganegaraan Burma 1982 yang tidak mengakui etnis Rohingya sebagai salah satu dari etnis-etnis resmi di Myanmar, hal tersebut mengakibatkan etnis ini mengalami diskriminasi. Tindakan penyangkalan ini juga bertentangan dengan upaya masyarakat internasional untuk menghapuskan keadaan tanpa kewarganegaraan yang menjadi tujuan dari Konvensi tentang Pengurangan Ketiadaan Kewarganegaraan. 


\section{Referensi}

\section{Buku}

Harper, Erica. International Law and Standard Applicable in Natural Disaster Situation. Jakarta: PT Grasindo. 2009. Kusumatmadja, Mochtar dan Agoes, Etty R. Pengantar Hukum Internasional. Bandung: PT Alumni. 2013.

Mauna, Boer. Hukum Internasional; Pengertian, Peranan, dan Fungsi dalam Era Dinamika Global.Edisi Pertama Cetakan Ke-4. Bandung: PT. Alumni. 2003.

Sefriani.Hukum Internasional Suatu Pengantar. Cetakan Kedua.Yogyakarta: PT Raja Grafindo Persada. 2015.

Smith, Rhona K.M., et al.. Hukum Hak Asasi Manusia. Cetakan Pertama. Ygyakarta: Pusat Studi Hak Asasi Manusia Universitas Islam Indonesia (PUSHAM UII). 2008.

Thontowi, Jawahir dan Iskandar, Pranoto.Hukum Internasional Kontemporer. Cetakan Pertama. Yogyakarta: PT Refika Aditama. 2006.

\section{Artikel/Jurnal}

Bangun, Budi Hermawan. ASEAN Intergovernmental Commission on Human Rights and Effectiveness of Fulfilling Human Rights Obligations of ASEAN Members States. Jambe Law Journal, Volume 1 Number 2. 2019. https://doi.org/10.22437 /jlj.1.2.231-249.

Rahminita, Siti Hediati. Implementasi Konvensi Penghapusan

Segala Bentuk Diskriminasi Terhadap Perempuan (CEDAW) Dan Korelasinya Terhadap Ketidaksetaraan Gender.Jurnal Ilmu Sosial, Vol 16 No. 1.Februari 2017.

Turnell, Sean. Myanmar's Fifty-Year Authoritarian Trap. Journal of International Affairs, Volume 65, Number 
1. 2011.Accessed February 5,
2020.www.jstor.org/stable/24388183.

\section{Laman}

AJ, Wisnu.Nobel Perdamaian dalam Nasib Etnis Rohingya. https://www.kompasiana.com/wisnuandangjaya/584 b9c7c509373e538b5f10a/nobel-perdamaian-dalamnasib-etnis-rohingya?page=alldiakses pada tanggal 24 Februari 2018, pukul 23.44 WIB.

BBC Indonesia. Siapa Sebenarnya Etnis Rohingya dan Enam HalLainyangHarusAndaKetahui.http://www.bbc.com/i ndonesia/dunia-4114969diakses tanggal 25

Februari 2018, pukul 21.03 WIB.

Ciptowiryono,Isharyanto.Merekayang Tidak Mempuyai Kewarganegaraan.https://www.kompasiana.com/isha ryanto/ 553003eb6ea8345b088b458c/mereka-yangtidak- mempunyai-kewarganegaraan.diakses tanggal 25 Februari 2018, pukul 17.03 WIB.

Jawa Pos. Negara-Negara Tujuan Pelarian Muslim Rohingya Untuk Mengungsikan

Diri.https://www.jawapos.com/internasional/ 03/09/2017/negara-negara-tujuan-pelarian-muslimrohingya-untuk-mengungsikan-diri/. diakses tanggal 06 Maret 2018, pukul 23.02 WIB.

Kompas.Myanmar Tolak Status Warga Negara Untuk Etnis Rohingya.http://internasional.kompas.com/read/201 3/11/21/

1933040/Myanmar.Tolak.Beri.Status.Warga.Negara.un t uk.Etnis.Rohingya, diakses tanggal 17 Februari 2018,pukul 11.20 WIB.

Kompas. YLBHI: Pelanggar HAM Warga Rohingya Harus DituntutPidanaInternasional. http://nasional.kompas.com/read/2017/09/04/0647 
4181/ylbhi-pelanggaran-ham-warga- rohingya-harusdituntut-pidana-internasional. Diakses tanggal 25 Februari 2018, pukul 22.16 WIB.

Merdeka.Myanmar Tolak Beri Kewarganegaraan Buat Muslim Rohingya.https://m.merdeka.com/dunia/myanmartolak-beri-kewarganegaraan-buat-muslim-rohingya.html,diakses tanggal 25 Februari 2018, pukul 00.09 WIB.

Ramli, Hamid. Mempersoalkan Status Kewarganegaraan Para TerdakwaKasusMakar(Bagian2).https://www.kompas iana.com/haramli/550dfdc5a33

311aa2dba7dd3/mempersoalkan-statuskewarganegaraan-para-terdakwa-kasus-makarbagian-2.diakses tanggal 25 Februari 2018, pukul 17.03 WIB.

Republika. Hikmahanto: Masalah Rohingya Terkait Status Kewarganegaraan.

http://m.republika.co.id/berita/internasional/ global/17/09/05/ovsaxl-hikmahanto-masalahrohingya-terkait-status-kewarganegaraan. diakses tanggal 25 Februari 2018, pukul 21.21 WIB.

Republika.SejarahSingkatRohingnyadiMyanmar.

http://internasional.republika.co.id/berita/internasio nal/global/17/09/03/ovp7fi-sejarah-singkatrohingya-di- myanmar. diaksestanggal 17 Februari 2018, pukul14.15 WIB.

Sindo Weekly.Rohingya,KaumTerbuang.http://www. sindoweekly.com/global/magz/no-29-tahunvi/rohingya-kaum-terbuang,diakses tanggal 18 Februari 2018, pukul 03.40 WIB.

Wisudawan,IAdi.RohingyadalamKacamataHukum Internasional.https://www.kompasiana.com/i.addi_wi sudawan/59c 2173db9a42c30e664aac2/rohingya- 
Rahmawati Novia Sigit\& Novianti

dalam-kacamata- hukum-internasional ?page=all. diakses tanggal 25 Februari 2018, pukul 23.57 Wib.

Uti Possidetis: Journal of International Law, Vol. 1, No. 3 (2020) 